\title{
The Effect of Fiscal Decentralization on the Accountability of City / District Government Financial Reporting in Indonesia and the Regional Government's Financial Performance as a Moderation Variable
}

\author{
Wahida Nurmuthmainnah ${ }^{1}$ \\ Magister Akuntansi \\ Fakultas Ekonomi dan Bisnis \\ Universitas Hasanuddin, Makassar, Indonesia
}

\begin{abstract}
This study aims to provide an overview of the effects of fiscal decentralization in proxies with regional independence and regional dependence on the central government regarding accountability of regional financial reporting and financial performance of Local Governments as moderating variables. The type of data used in this study is secondary data, panel data in the form of time series data from 2015 to 2017 and cross section data from 509 districts / cities in Indonesia. The sample selection in this study was purposive sampling by creating a cluster of western, central and eastern regions, so that 135 samples were obtained. The results showed that: (1) Regional independence had a positive effect on the accountability of local government financial reports. (2) Regional Dependence has a negative effect on the Accountability of Regional Government Financial Statements. (3) The financial performance of regional governments can moderate the influence of regional independence on the accountability of local government financial reports. (4) The financial performance of regional governments can moderate the effect of regional dependence on the accountability of local government financial statements.
\end{abstract}

Keywords:- Fiscal Decentralization, Regional Independence, Regional Dependence, Financial Performance, and Regional Financial Reporting Accountability.

\section{INTRODUCTION}

The drive for decentralization that occurs in various countries in the world is the most important that occurs in developing countries, which is related to several factors, for example the country's background or experience, its role in global globalization, setbacks in economic development, climate change and climate change. a sign of the existence of disintegration in several countries, and many are brought to life by centralistic governments in providing effective community services (Bird and Vaillancourt, 2000).

\author{
Syarifuddin $^{2}$, Mediaty ${ }^{3}$ \\ Departemen Akuntansi \\ Fakultas Ekonomi dan Bisnis \\ Universitas Hasanuddin, Makassar, Indonesia
}

Fiscal decentralization has been carried out in Indonesia since January 1, 2001. The implementation of regional autonomy raises various problems because regions have different capacities and capabilities in terms of finance, infrastructure availability, and human resource capacity (Syahrudin, 2006). This difference in ability has led to regional governments experiencing rapid progress and there are also regional governments that have actually experienced a setback so that the financial aspects of the central government must be assisted (Tahar and Mudofar, 2017).

Moisiu (2013) states the purpose of fiscal decentralization is to increase financial resources coming from the regions and use them to improve the quality and quantity of services needed by the community. With fiscal decentralization, it is expected that regions will have independence in increasing regional financial resources to finance regional spending and development activities in the regions. Fiscal decentralization cannot be achieved without the dependence of the regional government on the central government, which in fact the local government still expects equalization funds from the central government. So that the implementation of fiscal decentralization requires responsibility and transparency from local governments in terms of financial management. Accountability is a key component of fiscal decentralization reforms. Because with accountability the management of financial resources entrusted by the community has become more transparent.

The preparation and examination of local government financial statements is a step to realize accountability in government financial reporting. Currently, the development of the quality of financial reports and accountability for LKPD has increased from 2013 to 2017 but is not yet optimal, because it can be seen from the fact that there are still areas that receive a disclaimer opinion or do not provide an opinion. This indicates that the governance of district / city administration in Indonesia has improved. 
In general, regional governments in terms of regional spending and financing still depend on the central government. This can be seen from the source of revenue obtained by the region which is still dominated by donations and assistance from the central government, as well as the dependence of regional governments on the central government after regional autonomy still tends to be large. So far, more regional spending is used for routine shopping which is relatively less productive. Measurement of financial performance for the public benefit can be used as an evaluation and restore performance by comparing work schemes and their implementation. Besides that, it can also be used as a benchmark to improve performance, especially local government finances in the next period.

The quality of public services from housing housing and education, and health can represent indicators of the level of community growth on economic growth in Indonesia. Remote areas and infrastructure conditions such as inadequate road access become obstacles in the implementation of housing provision for all communities. Adequate facilities, infrastructure and infrastructure will support housing development. Thus, equal distribution of housing needs can be implemented for all levels of society.

The main characteristic of a region that is able to carry out autonomy according to Halim (2001) is, regional financial capability and dependence on central assistance must be as minimal as possible. DAK, which is specifically used for the construction and rehabilitation of physical facilities and infrastructure, if managed properly, can improve the quality of education, improve health services and at least reduce infrastructure damage. This is very important for overcoming poverty and building a more competitive national economy. The DAK allocation in the education, health and housing sectors compared to the total DAK allocation from 2015 to 2017 seems to fluctuate. Based on data from district / city financial publications in Indonesia, it was found that the ability of district / city regions in Indonesia experienced fluctuations and tended to decline in 2017.

Based on the problems that have been described, this study will examine the Effect of Fiscal Decentralization on Financial Reporting Accountability of City / Regency Governments in Indonesia and the Financial Performance of Regional Governments as a moderating variable.

\section{LITERATUR REVIEW AND HYPOTHESES DEVELOPMENT}

\section{A. Fiscal Decentralization and Financial Reporting Accountability}

The regional government is given the authority to regulate its own government affairs using financial assistance from the central government is demanded to increase the accountability of management and financial reporting of the government. Fiscal decentralization will improve the efficiency of regional financial management because local governments are able to obtain better information (compared to the central government) regarding the needs of the people in their regions (Richard and Francois, 2000).

Fontanella and Hilda Rossieta (2014) find fiscal decentralization in general to affect the possibility of regions having high financial reporting accountability, especially when viewed from the aspect of Regional Independence. This is seen from the improved audit opinion of the Regional Government which has independence from year to year. This is also in line with Mudhofar and Tahar (2016) research that regional independence has a positive effect on financial reporting accountability. From various empirical evidence in the previous literature, it can be concluded that the independence of funding through fiscal decentralization has a positive impact on financial accountability.

H1: Regional independence has a positive effect on the accountability of financial reporting

\section{B. Effect of Level of Regional Dependence on Regional Financial Reporting Accountability}

Halim (2001) explains that the main characteristic of a region that has implemented decentralization well is that the region has the ability and authority to explore financial resources, manage and use them to finance governance and reduce dependence on the central government. Ideally with fiscal decentralization that is complemented by a set of rules for management and adequate regional financial audits, the independence of regional funding through fiscal decentralization can improve the quality of financial management and reporting of local governments.

The high percentage of the balance fund amount indicates that the Regional Government is not independent in managing its income and can lead to lower performance accountability assessments. Research by Julitawati (2012) found that the Balancing Fund had a negative effect on the financial performance of District / City Governments, besides Fonatella and Rossieta (2014) and Mudhofa and Tahar (2016) stated that dependency on the Central Government had a negative effect on financial reporting accountability. Thus, the second hypothesis proposed is:

$\mathrm{H} 2$ : The level of regional dependence on the central government has a negative effect on the likelihood of high financial reporting accountability.

\section{Local Government Financial Performance, Fiscal Decentralization and Financial Reporting Accountability}

The level of regional independence as indicated by the ratio of PAD to total revenue illustrates the ability of the region to generate its own income, independent of the central government. Independence will encourage positive economic growth and increase investment volume in the regions. High independence and low dependence on the central government if supported by the implementation of good governance principles will improve the quality of public services (Adi, 2006). The good quality of public services also reflects the level of transparency and accountability of good government (Lin et. Al, 2010). 
Based on these arguments, the following hypotheses are proposed:

H3: The financial performance of local governments will moderate the effect of regional independence on the high accountability of financial reporting.

H4: The financial performance of local governments will moderate the effect of regional dependence on the central government on the high accountability of financial reporting.

This study examines and concludes the effect of fiscal decentralization proxied by regional independence through the Regional Original Revenue (PAD) approach and regional dependency through the Special Allocation Fund (DAK) approach to the central government on Accountability of regional financial reporting measured by BPK opinion. Regional Government financial performance as a moderating variable is measured by regional spending. The conceptual framework to help understand this research can be seen in Figure 1 below.

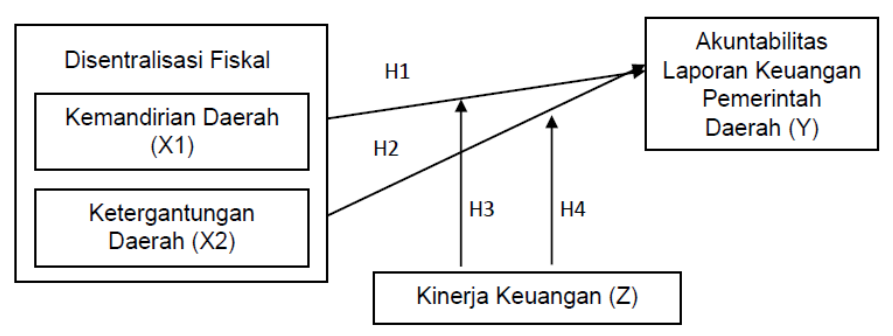

Fig 1:- Conceptual Framework

\section{RESEARCH METHODS}

The research design used is a quantitative type. Data sources in this study are secondary data consisting of: Local Own Revenue Data (PAD), Special Allocation Funds (DAK and Regional Expenditures from Realization of the 2015-2017 Regional Revenue and Expenditure Budget) Local Governments obtained from the Ministry of Finance website of the Director General of Central Financial Balance and Summary of Examination Results (IHPS) for 2015-2017. Audit opinion data obtained through the Supreme Audit Board website (BPK) The data collection method used is the method obtained through the website of the directorate general of financial balance, the Central Statistics Agency, and the Supreme Audit Agency The data analysis technique used is multiple linear regression.

The first equation model to test the Hypotheses H1, $\mathrm{H} 2$, and $\mathrm{H} 3$, namely:

$\mathrm{Y}=\alpha 0+\alpha 1 \times 1+\alpha 2 \times 2+\mathrm{e}$

Information:

Y : Akuntabilitas Pelaporan Keuangan Daerah

$\mathrm{X} 1 \quad$ : Kemandirian daerah

X2 : Ketergantungan daerah
The first equation model to test the Hypotheses $\mathrm{H} 4$ and H5, namely;

$$
\begin{aligned}
& \mathbf{Y =} \mathbf{\alpha 0}+\boldsymbol{\alpha 1} \mathbf{X} \mathbf{1}+\boldsymbol{\alpha 2} \mathbf{X} \mathbf{2}+\boldsymbol{\alpha 3} \mathbf{X} \mathbf{1} * \mathbf{Z}+\boldsymbol{\alpha 4} \mathbf{X} 2 * \mathbf{Z}+\mathbf{e} \\
& \text { Information: } \\
& \begin{array}{ll}
\mathrm{Y} & \text { : Akuntabilitas Pelaporan Keuangan Daerah } \\
\mathrm{X} 1 & \text { : Kemandirian Daerah } \\
\mathrm{X} 2 & \text { : Ketergantungan pada Pemerintah Pusat } \\
\mathrm{Z} & \text { : Kinerja Keuangan Pemerintah Daerah } \\
\mathrm{E} & \text { : Error }
\end{array}
\end{aligned}
$$

\section{RESULTS}

\section{A. Descriptive Statistics}

\begin{tabular}{|c|c|c|c|c|c|}
\hline \multicolumn{7}{|c|}{ Descriptive Statistics } \\
\hline Variabel & N & Minimum & Maksimum & Mean & $\begin{array}{c}\text { Standar } \\
\text { Deviasi }\end{array}$ \\
\hline X1 & 135 & 0,55 & 82,33 & 15,65 & 16,73 \\
\hline X2 & 135 & 0,29 & 100,00 & 59,87 & 21,74 \\
\hline Z & 135 & 18,30 & 93,07 & 38,83 & 11,59 \\
\hline Y & 135 & 1,00 & 4,20 & 2,63 & 0,96 \\
\hline \multicolumn{7}{|c|}{ Table 1:- Descriptive Statistics } \\
Source: Data processed, 2019 \\
\hline
\end{tabular}

Descriptive statistics in table 1 show the minimum value, maximum value, average, and standard deviation. Regional independence has a mean (mean) for three years of 15.65. Regional independence has a standard deviation of 16.73 higher than the mean (mean) of 15.65. Regional dependency has a mean (mean) for three years of 59.87 . Regional dependency has a standard deviation of 21.74 which is lower than the average (mean) of 59.87. The financial performance of local governments has a mean (mean) for three years of 38.83. The financial performance of local governments has a standard deviation of 11.60 lower than the average (mean) of 59.87. Accountability of local government financial statements has a mean (mean) for three years of 2.63. Accountability of local government financial statements has a standard deviation of 0.96 lower than the mean (mean) of 2.63.

\section{B. Classical Assumption Test \\ $>$ Normality Testing}

Normality Test aims to test whether in the regression model, the dependent variable and the independent variables both have normal distribution or not. A good regression model is having normal or near normal data distribution. The criterion value from the Normality test is Jarque-Bera> 0.05 . 


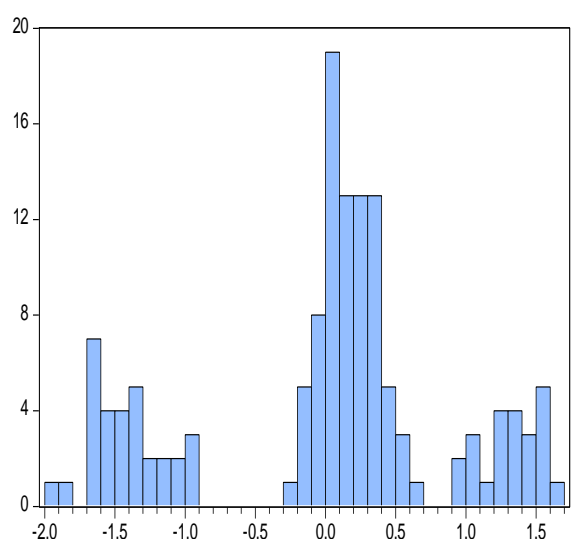

Series: Standardized Residuals Sample 20152017 Observations 135

Mean $\quad-3.36 \mathrm{e}-16$

Median $\quad 0.119724$

Maximum $\quad 1.629885$

Minimum $\quad-1.999271$

Std. Dev. $\quad 0.911886$

Skewness $\quad-0.385998$

Kurtosis $\quad 2.545002$

Jarque-Bera 4.516882 Probability $\quad 0.104513$

Fig 2:- Normality Test Results

Source: Data processed, 2019

Based on Figure 2, the normality test results obtained by the Jarque-Bera value of 4.516882 with a probability of 0.104513 . Thus the Jarque-Bera probability value is greater than alpha 0.05 , so the normality assumption is fulfilled.
Heteroscedasticity Test

\begin{tabular}{|c|c|c|}
\hline Variabel & Sig. & Keterangan \\
\hline $\begin{array}{c}\text { Kemandirian } \\
\text { Daerah }(\mathrm{X} 1)\end{array}$ & 0,4531 & Non Heteroskedastisitas \\
\hline $\begin{array}{c}\text { Ketergantungan } \\
\text { Daerah }(\mathrm{X} 2)\end{array}$ & 0,1861 & Non Heteroskedastisitas \\
\hline $\begin{array}{c}\text { Kinerja } \\
\text { Penyelenggaraan } \\
\text { Pemerintah }(\mathrm{Z})\end{array}$ & 0,3780 & Non Heteroskedastisitas \\
\hline
\end{tabular}

Table 2:- Heteroscedasticity Test Results

Source: Data processed, 2019

Based on Table 2, the results of residual analysis using Eviews 9 software obtained the probability value of the independent variables as a whole> alpha value of 0.05 so that the hypothesis $\mathrm{H} 0$ is accepted and concluded that there is no heteroscedasticity in the model.

\section{Multicollinearity Test}

\begin{tabular}{|c|c|c|c|}
\hline & Kemandirian Daerah (X1) & Ketergantungan Daerah (X2) & $\begin{array}{c}\text { Kinerja Penyelenggaraan } \\
\text { Pemerintah (Z) }\end{array}$ \\
\hline Kemandirian Daerah (X1) & 1.000000 & 0.641963 & 0.155750 \\
\hline $\begin{array}{c}\text { Ketergantungan Daerah (X2) } \\
\begin{array}{c}\text { Kinerja Penyelenggaraan } \\
\text { Pemerintah (Z) }\end{array}\end{array}$ & 0.641963 & 1.000000 & 0.489874 \\
\hline
\end{tabular}

Table 3: Multicollinearity Test Results

Source: Data processed, 2019

Based on the results of the correlation matrix output in Table 3, it appears that there is no correlation between the independent variables that are high above 0.80 . So, it can be concluded that there is no multicollinearity between independent variables.

C. Research Data Regression Analysis

$>$ Multiple Linear Regression Analysis

\begin{tabular}{|c|c|c|c|c|c|}
\hline Hubungan Variabel & Koefisien Regresi & Standard Error & t-Statistik & Prob. & Keterangan \\
\hline Konstanta & 0.9347 & 0.2170 & 4.308 & 0.0000 & Signifikan \\
\hline $\mathrm{X}_{1} \rightarrow \mathrm{Y}$ & 0.1721 & 0.0729 & 2.361 & 0.0204 & Signifikan \\
\hline $\mathrm{X}_{2} \rightarrow \mathrm{Y}$ & -0.0014 & 0.0006 & -2.324 & 0.0225 & $=0,7457$ \\
\hline $\mathrm{R}^{2}$ & $=5,6087$ \\
\hline F hitung & $=0,0000$ \\
\hline Sig. F hitung
\end{tabular}

Table 4:- Results of Multiple Linear Regression Analysis

Source: Data processed, 2019

The coefficient of determination R-square in Table 4 of the test results shows a value of 0.7457 . These results indicate that the accountability variable of local government financial statements is influenced by the regional independence variable (X1) and regional dependency (X2) by 74.57 percent, while the remaining 25.43 percent is influenced by other variables outside the independent variables examined in this study. 
Moderated Regression Analysis

\begin{tabular}{|c|c|c|c|c|c|}
\hline Hubungan Variabel & Koefisien Regresi & Standard Error & t-Statistik & Prob. & Keterangan \\
\hline Konstanta & -2.644162 & 0.689320 & -3.835897 & 0.0002 & Signifikan \\
\hline $\mathrm{Z}$ & -0.723133 & 0.296357 & -2.440075 & 0.0168 & Signifikan \\
\hline $\mathrm{X}_{1} * \mathrm{Z} \rightarrow \mathrm{Y}$ & 0.000188 & 0,0000744 & 2.520430 & 0.0136 & Signifikan \\
\hline $\mathrm{X}_{2} * \mathrm{Z} \rightarrow \mathrm{Y}$ & -0.000216 & 0,0000857 & -2.521814 & 0.0135 & $=0,7904$ \\
\hline $\mathrm{R}^{2}$ & $=6,5423$ & \\
\hline F hitung & $=0,0000$ & \\
\hline Sig. F hitung
\end{tabular}

Table 5: Moderation Regression Analysis Results

Source: Data processed, 2020

R-square determination coefficient values in Table 5 test results show the value of 0.7904 . These results indicate that the accountability variable of local government financial reports (Y) is influenced by 79.04 percent by regional independence (X1) and regional dependence after interacting with the local government financial performance variable ( $Z$ ), while the remaining 20.96 percent is influenced by variables other than the independent variables examined in this study.

Based on Table 5, it appears that local government financial variables $(Z)$ have a negative and significant effect on the accountability variables of local government financial reports (Y) so that they meet the assumptions as moderating variables (negative coefficient) and are categorized as pseudo moderation (quasi moderation) due to the interaction of independent variables (regional independence and regional dependency) with moderating variables (local government financial performance) are significant to the dependent variable (accountability of local government financial statements), and on the other hand moderation variables (local government financial performance) also have a significant effect on the dependent variable (financial statement accountability regional government).

\section{DISCUSSION}

H1: Regional Independence has a positive and significant effect on Regional Government Financial Reporting Accountability.

\section{$\operatorname{Area}(\mathrm{Y})$}

The results of multiple linear regression analysis for the effect of regional independence on financial reporting accountability of local governments have a probability value of $0.0204<0.05$. This value indicates that the influence of regional independence on the accountability of local government financial reporting is significant. In addition, the coefficient value for the effect of regional independence on regional government financial reporting accountability of 0.1721 indicates that the direction of positive influence indicates a direct relationship. This means that the higher the independence of the region will lead to the higher accountability of local government financial reporting.
This is in accordance with the grand design of fiscal decentralization that the vision of fiscal decentralization is to create an efficient allocation of national resources through transparent, accountable and equitable central and regional financial relations. The findings of this study are consistent with the opinion of Moisiu (2013), who explains that the level of regional autonomy is the most important indicator in determining accountability.

Regions that have succeeded in increasing their PAD significantly, indicate that the region has been able to utilize the existing potential optimally. Local taxes are the component that has the biggest contribution to PAD. In the high class, medium class and low class, there are still many regions with low regional capability below 50\%. Only Badung Regency has a high level of regional independence of $82.03 \%$ in 2017 and Surabaya City has a moderate level of regional independence of $55.56 \%$ in 2017 , so it can be interpreted that the regional government is approaching capable and independent in carrying out its regional autonomy affairs. While the difference is very high from the eastern region with the western and central regions, where the PAD cluster is in the western region and the middle region is higher than the high $\mathrm{PAD}$ cluster in the eastern region. The low PAD of a region is not because structurally the region is indeed poor or does not have potential financial resources, but rather is caused by central government policy. So far, the potential financial resources are controlled by the central government. In the existing regulations starting from the regional autonomy law and the regional government law, the regional government is given the obligation of all expenditures that are its duty but to collect regional income according to its authority is still limited.

H2: Regional Dependence has a negative and significant effect on the Accountability of Regional Government Financial Reporting

The results of multiple linear regression analysis for the effect of regional dependence on the accountability of local government financial statements have a probability value of $0.0225<0.05$. This value indicates that the influence of regional dependence on the accountability of local government financial statements is significant. In addition, the coefficient value for the effect of regional dependence on the accountability of local government financial statements of -0.0014 indicates that the direction 
of the negative influence, indicates a non-directional relationship. This means that the higher the dependency of the region will lead to the lower accountability of local government financial reports.

The second generation theory developed by Musgrave (1959) and Oates (1972) emphasizes the importance of assigning income and expenditure between levels of government. This theory explains how decentralized fiscal policies affect local government behavior. If the regional government has the authority to make regulations on the local economy, then the interference of the central government in the regional government approves. However, from the results of the study, the local government opposed the central government decided the local government refused the local government to take important decisions and the central government combined local government with local government. The findings of this study contradict Ladjin (2008), Fontanella and Hilda Rossieta (2014) and Mudhofar and Afrizal Tahar (2016) who find it dependent on the central government and do not support the financial accountability of local governments.

\section{H3: Regional Government Financial Performance moderates the influence of Regional Independence on Regional Government Financial Reporting Accountability}

The results of the regression analysis for the interaction between regional independence and local government financial performance have a probability value of $0.0136<0.05$ with the magnitude of the interaction effect 0.000188 . This value indicates that the financial performance of local governments can moderate the effect of regional independence on the accountability of local government financial reporting.

The results of this study are consistent with the theory of fiscal federalism which explains that the implementation of fiscal decentralization gives freedom to autonomous regions to improve their development better in improving the standard of living of their people, because local governments know more about the needs and desires of their people (local needs and local demand) than the central government so that service delivery is more responsive and able to bring the community to be more prosperous. The findings of this study are reinforced by the opinions of Moisiu (2013), Jaya and Sisdyani (2014), Purbasari and Bawono (2017), Fontanella and Hilda Rossieta (2014) who found that fiscal decentralization in the form of a degree of regional independence and the performance of government administration had a positive effect on likely high accountability of local government financial reporting.

This finding is not in line with Purbasari and Bawono (2017), Mudhofar and Afrizal Tahar (2016) who find the interaction between regional independence and performance does not show a statistically significant effect on the accountability of local government financial reporting. These results are biased so as to indicate that regional self-sufficiency has more dominant power than performance in influencing the accountability of local government financial reporting. This means that when the performance of a local government is good or bad, as long as it has independence it will tend to have good financial reporting accountability.

\section{H4: Regional Government Financial Performance moderates the effect of Regional Dependency on Regional Government Financial Reporting Accountability}

The results of the regression analysis for the interaction between regional dependency and local government financial performance have a probability value of $0.0135<0.05$ with the magnitude of the interaction effect of $-0,000216$. This value indicates that the financial performance of local governments can moderate the effect of regional dependence on regional government financial reporting accountability.

The Special Allocation Fund (DAK) in this case DAK in the field of education, DAK in the field of health, and DAK in housing and settlements is able to increase the accountability of regional financial reporting through improving the financial performance of regional governments. The results of this study illustrate that human development investment by the government can be seen from the allocation of government spending in the fields of education, health, housing and settlement. Wagner's theory states that in an economy if per capita income rises, government spending will also increase relative, mainly because the government must regulate relations that arise in society, law, education, recreation, culture and so on. This finding is in line with research by Juliawati et.al (2012), by Afryansyah (2013), Fontanella and Hilda Rossieta (2014) and Mudhofar and Afrizal Tahar (2016), and Juniawan and Suryantini (2018)

\section{CONCLUSION}

Based on the results of testing the research hypotheses and discussions that have been stated previously, then some conclusions can be drawn as follows.

Regional independence has a positive effect on the accountability of local government financial reporting. The district / city government in Indonesia shows that the regional government has managed PAD revenue transparently, so that the regional government is more accountable in managing finances and has an impact on the achievement of good opinion by BPK.

$>$ Regional dependence has a negative effect on the accountability of local government financial reporting. Very large regional dependence on balancing funds in many ways does not reflect regional accountability, this is because almost all regions have very high dependencies above 50\%. The high dependence of regional governments on the central government has resulted in local governments losing discretion to act (local discretion) to take important decisions and the central government has a high degree of interference 
with local governments. The higher the DAK, the higher the regional dependence on the center, the regional government has not been able to carry out its maximum government service obligations.

$>$ The financial performance of regional governments can moderate the effect of regional independence on the accountability of local government financial reporting. Local own revenue encourages high regional spending which ultimately increases the financial performance of local governments in the process of increasing local taxes and levies so that regional independence increases which will result in accountability of local government financial reporting. Regional income in financing the needs of local communities, among others, in terms of free education, free health, subsidized housing is more effective if it is right on target to the people who need it and infrastructure development to support productive sectors so as to be able to increase community income.

$>$ The financial performance of local governments can moderate the effect of regional dependence on regional government financial reporting accountability. The Special Allocation Fund (DAK) in this case DAK in the field of education, DAK in the field of health, and DAK in housing and settlements is able to increase the accountability of regional financial reporting through improving the financial performance of local governments. DAK can be used effectively and wisely by local governments, has an impact on improving the quality of education, health, housing and habitable residential areas, and supporting infrastructure for the economy of the community which will certainly encourage financial performance to increase income so that regional dependence on the central government decreases.

Based on the research conclusions, a number of suggestions can be proposed in order to examine the research space by including moderation of interventions to add references related to research related to quantitative research. And research development can also be done by adding primary data sources to get more complete and supportive data quality.

\section{REFERENCES}

[1]. Adi, Priyo Hari. 2006, Hubungan Antara Pertumbuhan Ekonomi, Belanja Pembangunan dan PendapatanAsli Daerah. Proceddding Simposium Nasional Akuntansi IX, Padang.

[2]. Afryansyah, Rahmad Dian. 2013. Faktor-Faktor yang Mempengaruhi Pengungkapan Informasi Akuntansi Di Internet Oleh Pemerintah Daerah. Diponegoro Journal of Accounting, Vol. 0, pp. 702 - 712, Jul. 2013.

[3]. Bird, Richard dan Vaillancourt, Francois. 2000. Desentralisasi Fiskal di Negara -Negara Berkembang, Cetakan 1, PT. Gramedia Pustaka Utama, Jakarta. (Terjemahan)

[4]. Fontanella, A. dan H. Rossieta. 2014. Pengaruh Desentralisasi Fiskal Dan Kinerja Terhadap Akuntabilitas Pelaporan Keuangan Pemda Di
Indonesia. Paper Dipresentasikan pada Simposium Nasional Akuntansi XVII, Lombok.

[5]. Halim, Abdul. 2001. Analisis Diskripsi Pengaruh Fiskal Stress pada APBD Pemerintah Kabupaten dan Kota di Jawa Tengah. Kompak. STIE YO. Yogyakarta.

[6]. Jaya, J. D dan Eka Ardhani Sisdyani. 2014. Pengaruh Pendapatan Asli Daerah, Dana Alokasi Umum, dan Belanja Modal pada Kelengkapan Pengungkapan Informasi Keuangan Daerah Melalui Situs Resmi Pemerintah Provinsi. E-Jurnal Akuntansi Universitas Udayana. 9.2 (2014): 285-303

[7]. Juliawati, Ebit. Darwanis dan Jalaluddin. 2012. Pengaruh Pendapatan Asli Daerah (PAD) dan Dana Perimbangan terhadap Kinerja Keuangan Kabupaten/Kota di Provinsi Aceh. Jurnal Akuntansi Syiah Kuala. VolumeI. Tahun I No. 1.

[8]. Juniawan, M. Ari dan Ni Putu Santi Suryantini. 2018. Pengaruh PAD, DAU, dan DAK Terhadap Belanja Modal Kota dan Kabupaten di Provinsi Bali. E-Jurnal Manajemen Unud, Vol. 7, No. 3, 2018: 1255-1281

[9]. Ladjin, Nurjanna. 2008. Analisis Kemandirian Fiskal di Era Otonomi Daerah (Studi Kasus di Provinsi Sulawesi Tengah). Tesis Universitas Diponegoro Semarang.

[10]. Lewis, Blane. 2013. Local Government Capital Spending in Indonesia: Impact of Intergovernmental Fiscal Transfer. Australian National University.

[11]. Lin, Ming-lan., Lee, Yuan-Duen., Ho, Tsai-Neng. 2010. Applying integrated EA/AHP to evaluate the economic performance of local governments in China. European. Journal of Operational Research, 209 (2011) 129-140.

[12]. Moisiu, Alexander. 2013. Decentralizations and The Increased autonomy in Local Governments, ProcediaSocial and Behavioral Sciences, pp.459-463

[13]. Mudhofa, K. dan A. Tahar. 2016. Pengaruh Desentralisasi Fiskal dan Kinerja Terhadap Akuntabilitas Pelaporan Keuangan Pemerintah Daerah di Indonesia: Efek Moderasi dari Kinerja. Jurnal Akuntansi dan Investasi, Vol. 17 No. 2, Hlm: 176185.

[14]. Musgrave, R. A. 1959. The Theory of Public Finance : A Study in Public Economy. New York: McGraw Hill.

[15]. Oates, W.E. 1972. Fiscal Federalism. New York : Harcourt Brace Javanovic

[16]. Purbasari dan Bawono. 2017. Pengaruh Desentralisasi Fiskal, Sistem Pengendalian Internal dan Kinerja Pemerintah Daerah terhadap Akuntabilitas Laporan Keuangan. Fakultas Ekonomi dan Bisnis: Universitas Muhammadiyah Surakarta.

[17]. Syahruddin. 2006. Desentralisasi Fiskal: Perlu Penyempurnaan Kebijakan dan Implementasi Yang Konsisten. 